\title{
Study on AJWAIN (Trachyspermum ammisprage) Based Intercropping System for Enhancing System Productivity
}

\author{
Mahendra Parsoya ${ }^{1}$, R.S. Mehta ${ }^{2}$, S.S. Meena ${ }^{3}$, Vinod Kumar ${ }^{4}{\text { and } \text { Rajveer }^{5 *}}^{*}$ \\ ${ }^{1}$ Agronomy, MJRP University, Jaipur, Rajasthan, India \\ ${ }^{2}$ Agronomy, ICAR-CAZRI, Regional Research Station, Pali-Marwar, Rajasthan, India \\ ${ }^{3}$ Agronomy, ICAR-NRCSS,Tabiji, Ajmer, Rajasthan, India \\ ${ }^{4}$ Agronomy MJRP University Jaipur Rajasthan India \\ ${ }^{5}$ SMS (Soil Science) SKRAU Bikaner, Rajasthan, India \\ *Corresponding author
}

\section{A B S T R A C T}

\begin{tabular}{|l|}
\hline Ke y w or d s \\
Ajwain, Inter- \\
cropping, Net \\
returns, LER, Yield \\
\hline Article Info \\
\hline Accepted: \\
25 May 2018 \\
Available Online: \\
10 June 2018 \\
\hline \hline
\end{tabular}

A field experiment comprising ten treatments of intercropping systems replicated four times, was conducted in Randomized Block Design during rabi season, 2016-17. Results indicated that sole ajwain exhibited the higher plant height and number of branches per plant at 60 DAS, 90 DAS and at harvest as compared to different intercropping system. Further, results showed that sole ajwain gave significantly highest values of yield attributes viz., number of umbels per plant, number of umbellate per umbel, seeds per umbellate, 1000 - seed weight, seed yield per plant and seed yield per hectare as compared to different intercropping system. Sole french radish, sole Knolkhol and sole fenugreek resulted higher plant population, plant height at harvest, number of leaves per plant, diameter of curd and fresh marketable yield as compared to different intercropping systems. Intercropping of ajwain with french radish in 1:1 row ratio resulted significantly higher land equivalent ratio (1.81), ajwain equivalent yield $(3274 \mathrm{~kg} / \mathrm{ha})$, gross return (Rs. $\left.327388 /-\mathrm{ha}^{-1}\right)$, net return (Rs.270238/- ha ${ }^{-1}$ ) and BCR (4.72) followed by intercropping of ajwain with french radish in 2:2 paired row ratio. Ajwain + Fenugreek 1:1 and 2:2 recorded significantly higher N, P and K $(90.09,6.92$ and $282.52 \mathrm{~kg}$ per ha) availability in soil after harvest of crops as compared to other intercropping. Thus, it is inferred that intercropping of ajwain + french radish in 1:1 row ratio is better for realizing higher system productivity and economic returns.

\section{Introduction}

India is the world's largest producers, consumers and exporter of seed spices. Ajwain (Trachyspermum ammi sprague) generally called as ' 'ajwain' 'belongs to the Apiaceae family. It is mainly grown in Rajasthan, Gujarat, Madhya Pradesh, Tamilnadu and Uttar Pradesh. Ajwain is an important seed spice crop of Rajasthan which. Area, production and productivity of ajwain in Rajasthan are 0.06 lakh hectares, 0.04 lakh metric tones, and $680 \mathrm{~kg} / \mathrm{ha}$, respectively (Anon - 2015). Ahlawat and Gangaiah (2010) reported higher system productivity in chickpea intercropped with linseed over sole chickpea. Mustard and chickpea intercropping have exhibited higher land equivalent ratio 
(1.41) over in sole crops (Thomaset al., 2010). Shortages of vegetables in the country have focused the attention on intercropping systems which have capacity to improve the physical, biological and chemical properties of soil (Mehta et al. 2010). Thus productivity of system can be enhanced with change in crop configuration for inclusion of other crops in the existing cropping system. Hence the study on effect of ajwain based inter-cropping system with vegetable crops was undertaken with an objective to find most efficient inter cropping system for realizing higher system productivity

\section{Materials and Methods}

The experiment was laid out at Research farm of ICAR-National Research Center on Seed Spices, Ajmer, Rajasthan, during 'Rabi' season of 2016-17. The soil of research farm is sandy loam, poor in fertility and water

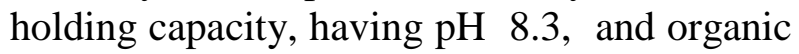
carbon $0.23 \%$, available $\mathrm{N} 100.38 \mathrm{~kg} / \mathrm{ha}$, $\mathrm{P}_{2} \mathrm{O}_{5} 7.76 \mathrm{~kg} / \mathrm{ha}, \mathrm{K}_{2} \mathrm{O} 392.26 \mathrm{~kg} / \mathrm{ha}$.. The experiment comprising of 10 treatments viz., sole ajwain, sole French radish, sole knolkhol, sole fenugreek, ajwain intercropping with French radish, knolkhol and fenugreek different row ratios (1:1 and 2:2) was laid in randomized block design with four replications. As per technical programme one row of French radish, knolkhol and fenugreek was added between two rows of ajwain in 1:1 intercropping ratio and two rows of vegetable crops were added in a pair of two rows of ajwain (paired row having 25/35 $\mathrm{cm}$ ). A uniform recommended dose of $60 \mathrm{Kg} \mathrm{N}$ and $40 \mathrm{~kg} \mathrm{P}_{2} \mathrm{O}_{5} \mathrm{ha}^{-1}$ and $30 \mathrm{~kg} \mathrm{~K} \mathrm{O}_{2}$ for sole ajwain, $120 \mathrm{~kg} \mathrm{~N}, 60 \mathrm{~kg}_{2} \mathrm{O}_{5}$ and $40 \mathrm{~kg} \mathrm{~K} \mathrm{~K}_{2} \mathrm{O}$ for sole knolkhol, $100 \mathrm{~kg} \mathrm{~N}, 50 \mathrm{~kg} \mathrm{P}_{2} \mathrm{O}_{5}$ and 40 $\mathrm{kg} \mathrm{K} \mathrm{K}_{2} \mathrm{O}$ for french radish and $20 \mathrm{~kg} \mathrm{~N}, 40 \mathrm{~kg}$ $\mathrm{P}_{2} \mathrm{O}_{5}$ and $30 \mathrm{~kg} \mathrm{~K}_{2} \mathrm{O}$ for fenugreek was applied. In intercropping of ajwain and vegetables $100 \%$ NPK of sole ajwain and 50 $\%$ NPK of respective vegetables were applied.
$1 / 3 \mathrm{~N}$ and full dose of phosphorus and potash were applied at the time of sowing and remaining 2/3 $\mathrm{N}$ was applied with low pressure drip irrigation through urea at an interval of 8 days. The standard agronomic practices were applied for raising healthy ajwain crop as well as French radish, knolkhol and fenugreek. Immediately after sowing irrigation was provided with low pressure drip irrigation having normal operating pressure of $0.1 \mathrm{~kg} \mathrm{sq} \mathrm{cm}^{-}{ }^{-}$. Each plot has 5 lateral lines of drip, the drippers were fitted on lateral lines at the distance of $30 \mathrm{~cm}$. Each dripper had discharge rate of 1.25 litter /hour. First irrigation was given just after sowing and subsequent irrigations were provided at four days interval based on $80 \mathrm{CPE}$. Total 33 irrigations, each four days interval were given to crop starting from sowing to 15 days before harvesting. Yield of component crop was calculated based on proportionate area occupied by them.The yield of ajwain, French radish, knolkhol and fenugreek was converted into ajwain equivalent yield as per prevailing rates in market and treatment evaluation was done accordingly. Economic analysis of the different treatment was done for drawing conclusion.

\section{Results and Discussion}

\section{Yield parameters and yield of ajwain}

Significantly higher plant heights, number of branches /plant at maturity of ajwain were recorded in sole ajwain over all intercropping systems (Table 1). In respect to intercropping systems, significantly higher growth parameters of ajwain were recorded with $1: 1$ ratio of ajwain and component crops viz. French radish, knolkhol and fenugreek. The higher plant height in sole ajwain andin 1:1 ratio intercropping was on account of less competition for sunlight, space, nutrient and water as compared to other ratio. Tiwari et al. (2002) reported depressing effect on growth 
and performance of fennel when intercropped with vegetable crop. Similarly,Nandekaret al. (1995) reported decrease in growth parameters of potato with intercropping.

The higher yield attributes and yield of ajwain with French radish, knolkhol and fenugreek intercrops were recorded in 1:1 ratio. Intercropping of ajwain with French radish resulted in significantly higher yield and yield attributes ofajwain over khnolkhol and fenugreek inter- cropping (Table 2).The higher yield attributes and yield of ajwain in 1:1 ratio with all intercrops might be due to less competition for space, sunlight, water and nutrients between ajwain and component crops which gave higher growth parameters resulting in higher translocation of photosynthates from source to sink resulting in higher yield and yield attributes of ajwain. Tiwari et al. (2002) reported depressing effect on growth and performance of fennel when intercropped with vegetable crop. Similarly,Nandekaret al. (1995) reported decrease in yield of potato with intercropping.

Table.1 Effect of intercropping system on growth and yield attributes of ajwain at harvest

\begin{tabular}{|c|c|c|c|c|c|c|c|}
\hline Treatment & $\begin{array}{l}\text { Plant } \\
\text { Height } \\
(\mathrm{cm})\end{array}$ & $\begin{array}{l}\text { Branches/ } \\
\text { plant }\end{array}$ & $\begin{array}{l}\text { Umbels/ } \\
\text { plant }\end{array}$ & $\begin{array}{c}\text { Umbellates/ } \\
\text { umbel }\end{array}$ & $\begin{array}{c}\text { Seeds/ } \\
\text { umbellate }\end{array}$ & $\begin{array}{c}1,000 \text { seed } \\
\text { weight } \\
\text { (g) }\end{array}$ & $\begin{array}{r}\text { Seed } \\
\text { yield/ } \\
\text { plant }(g)\end{array}$ \\
\hline Sole Ajwain & 117.91 & 16.70 & 170.15 & 14.30 & 18.25 & 1.38 & 61.07 \\
\hline Sole French radish & - & - & - & - & - & - & - \\
\hline Sole Knolkhol & - & - & - & - & - & - & - \\
\hline Sole Fenugreek & - & - & - & - & - & - & - \\
\hline Ajwain + French radish 1:1 & 110.09 & 15.80 & 169.65 & 14.20 & 17.95 & 1.25 & 54.18 \\
\hline Ajwain + French radish 2:2 & 108.19 & 15.45 & 168.50 & 14.00 & 17.85 & 1.18 & 49.72 \\
\hline Ajwain + Knolkhol 1:1 & 109.96 & 15.75 & 169.10 & 14.20 & 17.95 & 1.23 & 52.92 \\
\hline Ajwain + Knolkhol 2:2 & 108.13 & 15.40 & 168.45 & 14.00 & 17.75 & 1.16 & 48.65 \\
\hline Ajwain + Fenugreek 1:1 & 109.09 & 15.65 & 169.30 & 14.10 & 17.95 & 1.21 & 51.86 \\
\hline Ajwain + Fenugreek 2:2 & 108.05 & 15.15 & 168.20 & 13.95 & 17.85 & 1.13 & 47.34 \\
\hline $\mathrm{SEm}+$ & 2.88 & 0.64 & 3.61 & 0.44 & 0.47 & 0.04 & 2.13 \\
\hline $\mathrm{CD}(\mathrm{P}=0.05)$ & NS & NS & NS & NS & NS & NS & 6.32 \\
\hline
\end{tabular}


Table 2. Effect of different intercropping on growth and yield attributes of component crops

\begin{tabular}{|c|c|c|c|c|c|}
\hline Treatment & Plant population & $\begin{array}{l}\text { Plant hieght } \\
\quad(\mathrm{cm})\end{array}$ & $\begin{array}{c}\text { Number of } \\
\text { Leaves/plant }\end{array}$ & $\begin{array}{l}\text { Days taken to } \\
\text { maturity }\end{array}$ & $\begin{array}{c}\text { Days taken to } \\
\text { harvest }\end{array}$ \\
\hline Sole Ajwain & - & - & - & - & - \\
\hline Sole French radish & 2.26 & 44.96 & 14.80 & 51.05 & 53.8 \\
\hline Sole Knolkhol & 2.24 & 34.26 & 24.03 & 64.10 & \\
\hline Sole Fenugreek & 2.24 & 30.69 & 25.96 & - & 54.95 \\
\hline Ajwain + French radish $1: 1$ & 2.15 & 43.19 & 14.05 & 48.75 & 51.70 \\
\hline Ajwain + French radish 2:2 & 1.70 & 42.25 & 13.95 & 48.20 & 51.00 \\
\hline Ajwain + Knolkhol 1:1 & 2.10 & 33.01 & 23.10 & 63.35 & \\
\hline Ajwain + Knolkhol 2:2 & 1.80 & 32.08 & 22.05 & 62.85 & \\
\hline Ajwain + Fenugreek 1:1 & 2.15 & 29.39 & 25.75 & - & 54.30 \\
\hline Ajwain + Fenugreek 2:2 & 1.80 & 29.22 & 24.25 & - & 54.20 \\
\hline SEm +_ & - & - & - & - & - \\
\hline $\mathrm{CD}(\mathrm{P}=0.05)$ & - & - & - & - & - \\
\hline
\end{tabular}

Table 3. Effect of intercropping systems on yield of ajwain and component crops and system productivity (ajwainequivalent yield)

Treatment

Seed yield of

Ajwain (q/ha)
Marketable yield of intercrops ( $\mathrm{q} / \mathrm{ha})$
Ajwain equivalent yield ( $q / h a)$
Sole Ajwain

Sole French radish

Sole Knolkhol

Sole Fenugreek

Ajwain + French radish 1:1

Ajwain + French radish 2:2

Ajwain + Knolkhol 1:1

Ajwain + Knolkhol 2:2

Ajwain + Fenugreek 1:1

Ajwain + Fenugreek 2:2

$\mathrm{SEm}+$

$\mathrm{CD}(\mathrm{P}=0.05)$
13.77

$-$

12.21

11.18

11.90

10.94

11.69

10.63

4.8

14.1
$-$

274.30

138.84

273.39

256.61

254.70

121.79

113.76

246.53

237.75

$-$
13.77

21.94

13.84

21.87

32.74

31.56

24.09

22.32

31.42

29.65

0.89

2.58 
Table 4. Effect of intercropping systems on economics and land

\begin{tabular}{|c|c|c|c|c|c|}
\hline Treatment & $\begin{array}{r}\text { Cost of } \\
\text { cultivation } \\
\text { (Rs/ha) }\end{array}$ & $\begin{array}{l}\text { Gross } \\
\text { returns } \\
\quad(R S / h a)\end{array}$ & $\begin{array}{l}\text { Net returns } \\
\text { (Rs/ha) }\end{array}$ & & LER \\
\hline Sole Ajwain & 53000 & 137700 & 84700 & 1.59 & 1.00 \\
\hline Sole French radish & 61550 & 219440 & 157890 & 2.56 & 1.00 \\
\hline Sole Knolkhol & 64300 & 138440 & 74140 & 1.15 & 1.00 \\
\hline Sole Fenugreek & 66050 & 218712 & 152662 & 2.31 & 1.00 \\
\hline Ajwain + French radish 1:1 & 57150 & 327388 & 270238 & 4.72 & 1.81 \\
\hline Ajwain + French radish 2:2 & 57150 & 315660 & 258510 & 4.52 & 1.73 \\
\hline Ajwain + Knolkhol 1:1 & 58950 & 240890 & 181940 & 3.08 & 1.73 \\
\hline Ajwain + Knolkhol 2:2 & 58950 & 223160 & 164210 & 2.75 & 1.61 \\
\hline Ajwain + Fenugreek 1:1 & 60038 & 314224 & 254186 & 4.23 & 1.74 \\
\hline Ajwain + Fenugreek 2:2 & 60038 & 296500 & 236462 & 3.93 & 1.63 \\
\hline $\mathrm{SEm}+$ & - & - & - & 0.05 & 0.05 \\
\hline $\mathrm{CD}(\mathrm{P}=0.05)$ & - & - & - & 0.15 & 0.15 \\
\hline
\end{tabular}

\section{Yields attributes and yield of intercrops}

Yield attributes and yield of intercrops was recorded higher in respective sole crops as compared to intercropping with ajwain. Further, perusal of data in Table 2 and 3 revealed that among different inter cropping ratios, the higher yield and yield attributes of intercrops was exhibited in 1:1 ratio. Intercropping of ajwain + French radish in all the ratios resulted higher economic yield of french radish as compared to knolkhol and fenugreek. The higher yield of all the intercrops crops in 1:1 ratio was on account of higher plant population due to accommodation of more number of rows in between interspaces as compared to 2:2 ratio. Mehta et al (2012 and 2015) also reported higher yield of intercrops in 1:1 row ratio with fennel.

\section{System productivity}

Significantly higher ajwain equivalent yield (AEY) and land equivalent ratio (LER) of the system was re- corded in intercropping as compared to sole cropping (Table 4). Ajwain + French radish in all intercroppingratios resulted higher AEY and LER as compared to its intercropping with knolkhol and fenugreek. Further analysis showed that 1:1 ratio with all intercrops proved superior resulting in higher AEY and LER over 2:2 ratio. Ajwain + French radish in 1:1 ratio exhibited 175.01 and $81 \%$ higher AEY and LER, respectively over sole ajwain. The higher AEY and LER in intercropping system was on account of additional yield of intercrops without much reduction in yield of base crop. The highest AEY and LER in 1:1 ratio with French radish, knolkhol and fenugreek was due to proportionately less 
reduction in ajwain yield as compared with 2:2 ratio resulting in better yield of intercrop. Bhati (1992) and Mehta et.al (2015) reported higher fennel equivalent yield in intercropping as compared to sole crops. Similarly, Ahlawat and Gangaiah (2010)and also reported higher system productivity in chickpea intercropped with linseed over sole chickpea. Thomas et al. (2010) reported the highest LER of 1.41 in mustard and chickpea intercropping over sole crops. Mehta et. al (2015) also reported higher system productivity and LER on intercropping systems over sole intercropping.

\section{Economic analysis}

Intercropping of ajwain + French radish in 1:1 ratio exhibited significantly higher net return (Rs 270238/ha) and B: C ratio (4.72) which was 175.01 and $81 \%$ higher, respectively over ajwain + French radish (2:2). Ajwain+French radish/knolkhol/fenugreek in 1:1 ratio proved superior which resulted in higher net return and B: $\mathrm{C}$ ratio over 2:2 ratio. Similar benefits of inter- cropping on economics in fenugreek + mustard was reported by Yadav et al, (2003). Khurana and Bhatia (1995) in intercropping of onion and potato with fennel and Ahlawat and Gangaiah (2010) in chickpea + linseed reported similar results.

It is concluded that intercropping of ajwain and French radish in 1:1 ratio is promising for higher productivity and profitability.

\section{References}

Ahlawat, I.P.S. and Gangaiah. B. 2010. Effect of land configuration and irrigation on sole and linseed (Linumusitatis simum) intercropped chickpea (Cicerarietinum). Indian Journal of Agricultural Sciences 80(3): 248-249.

Bhati, D.S. 1992. Intercropping in fennel (Foeniculumvulgare). Indian Journal of Agricultural-Sciences62(3): 218-219.
Khurana, S.C. and Bhatia, A.K. 1995.Intercropping of onion and fennel with potato. Journal of the Indian Potato Association22(3-4): 140-145.

Mehta, R.S., Meena, S.S.and Anwer, M.M. 2010.Performance of coriander (Coriandrumsativum) based intercropping system. Indian Journal of Agronomy, 55 (4): 286-289.

Mehta, R.SMalhotra, S.K., Lal,G. Meena S.S., Singh R.,Aishwath O.P., Sharma Y.K., Kant,K and Khan,M.A 2012.Influence of inter cropping systems with varying fertility levels on yield and profitability of fennel (Foeniculumvulgare Mill.)International J. Seed Spices2(1):2427.

Mehta, R. S, Singh B., Meena S. S., LalG.,Singh R. and Aishwath, O. P. 2015.Fennel (Foeniculumvulgare Mill.) based intercropping for higher system productivity,International J. Seed Spices5(1):56-62.

Nandekar, D.N., Sharma, T.R., Sharma, R.C. 1995. Effect of potato based intercropping system on yield and economics. Journal of the Indian Potato Association22(3-4): 159-161.

Thomas, A., Sharma, U.C., Thenua, O.V.S.andShivakumar, B.G. 2010. Effect of levels of irrigation and fertility on yield and economics of chickpea (Cicerarietinum) and Indian mustard (Brassica juncea) under sole and intercropping systems Indian Journal of Agricultural Sciences80(5): 372-376.

Tiwari, R.S., Ankur, A, Sengar, S.C. and Agarwal, A. 2002. Effect of intercropping on yield and economics of fennel (Foeniculumvulgare Mill.). Crop Research Hisar23(2): 369-374.

Yadav, P.C., MakhanLal and Agarwal, P. 2003. Intercropping of mustard in fenugreek (Trigonellafoenymgraecum L) under varying fertility levels. Journal of Farming System Research and Development 8(1): 110-111. 


\section{How to cite this article:}

MahendraParsoya, R.S. Mehta, S.S. Meena, Vinod Kumar and Rajveer. 2018. Study on AJWAIN (Trachyspermum ammisprage) Based Intercropping System for Enhancing System Productivity. Int.J.Curr.Microbiol.App.Sci. 7(06): 3490-3496. doi: https://doi.org/10.20546/ijcmas.2018.706.408 